\title{
INVESTIGATING THE SOCIAL RETURN ON TECHNICAL INVESTMENTS
}

\author{
Author(s): \\ T. Jenei - J. T. Kiss \\ Affiliation: \\ University of Debrecen, Faculty of Engineering, 4032. Debrecen, Ótemető u. 2-4. \\ Email address: \\ jeneit@eng.unideb.hu, tkiss@eng.unideb.hu
}

\begin{abstract}
In this paper, we examine the importance of the use of the social Return of Investment (SROI) method by investors, company managers in the evaluation of a particular technical investment or activity. The SROI analysis method differs from other financial valuation methods because it collects and analyses information about the social value of the resources used by the activities. In most cases, the economic analysis of investments does not contain such information, and neither such that would examine the impact of these resources on society. As a result of the SROI analysis, qualitative, quantitative and financial data are available on the project, providing the end-user with information on the social values of the examined investment. This issue is particularly important for environmental investments financed by the European Union.
\end{abstract}

\section{Keywords}

Technical investments, measuring external effects, social return, SROI, cost-benefit analysis

\section{Introduction}

The result of an investment or activity is that the users of the project or service benefit directly from it. For most investments, such external economic effects that do not directly manifest at the users of the project and do not involve direct financial compensation. These are the external effects of investments [1].

Several methods can be used to estimate user benefits. On the one hand, the benefits can be approached by quantifying the resource savings achieved by the project. On the other hand, by estimating financial revenues if it adequately reflects the benefit to the users of the infrastructure created by the project. During the analysis it is necessary to examine the method of estimating the revenues, which can be used to conclude what external effects do not appear in the financial revenues [2].

The main purpose of the research is to quantify the effects that cannot be described by conventional financial methods. In the case of estimating external benefits, the methods for quantifying the effects may vary with each project. It may not be possible to quantify all the effects, so the impact should be described qualitatively in the analysis.

\section{Cost-benefit analysis of external effects}

External effect means that the economic activity in question also involves a participant (third party) who is not involved in the activity [3].

In the case of external effects, the welfare of such persons who do not participate in the transaction as either producers or buyers grows or declines. This effect does not appear in the course of corporate activity, so the price of the product or service does not include its benefits and costs. A further feature is that external effects are „uncompensated welfare changes" [4].

"The decisive feature of external economic effects is that there are goods that people appreciate, but are not the subject of market sales" [5]. In the framework of a research program [6] it was investigated that in case of agricultural cultivation and good farming strategy a significant reduction of $\mathrm{CO} 2$ emissions can be achieved, which can have a positive external effect on society and the environment.

The external economic impact is nothing else but an unintentional, unconscious impact on the level of welfare of one or more economic players. External economic impacts can be positive or negative and can affect producers and consumers alike.

-An adverse external effect is when the party concerned has suffered damage as a result of the 
external impact. This can be a financial loss, loss that can be directly or indirectly determined or not measured in currency. Such effects are negative externalities.

-In the case of a favorable external effect, the given externalities have a positive effect on the stakeholders and their environment. When it comes to a business, it affects its profit favorably as long as it affects the consumer; it increases its level of welfare. These are the so-called positive externalities. Within negative externalities, a distinction can be made between technological and financial impacts. Environmental protection mainly deals with technological impacts.

A common method of dealing with negative externalities of activities that affect a large part of society is that the state tries to limit them with regulations. In these cases the objective is to prevent the development of externalities.

The state can intervene effectively in the case of such negative externalities that affect many people. Tax is levied on activities that result in negative externalities to be suppressed, or stimulate the activity in case of positive externalities. The abovementioned instruments for reducing or eliminating negative externalities are not applicable to all economic sectors. For example, in the case of biomass production, the use of these instruments is very complicated [7].

In the socio-economic analysis, the benefits and costs of cash flows are interpreted broadly. Not only are the revenues and expenditures of private projects that can be captured in the relevant financial and financial sense, but also the secondary effects of the project. What are the costs and benefits for the community and society? The project may have an impact on the environment, human health, employment, etc. The secondary effects of the project can be relatively well defined its quantification is difficult, however. The cash flows calculated in the socio-economic assessment take the benefits for the community that private projects do not calculate with into account. These are the external effects that are incorporated as separate points into the cash flow of the projects. The purpose of this amendment is to determine what other cash flow, profit or cost there is compared to private projects at a social level.

\section{Method and indicator of social return on investments (SROI)}

Social return on investments (SROI) is an analytical method for measuring social, economic and environmental values that do not appear in the traditional financial analysis of an investment.
While in financial analyses the ROI (Return on Investment) is a single indicator, SROI is not just a single indicator, but also an analysis method. The SROI method of analysis is based on seven principles and consists of six sections, which were also published in the „Guide for calculating the social return on investment" [8].

The calculation and analysis of the SROI indicator deals with the fifth stage of the method. Thus there is a difference between „SROI” as an indicator and the „SROI method".

The SROI method is a consistent quantitative approach to analyzing and managing the effects of a project or the activities of an enterprise or social organization.

The SROI shows the monetary value of social, economic and environmental changes resulting from these effects and activities, which generally do not have market value [8]. This approach demonstrates how effectively an enterprise can use its resources to create value for society. The SROI method attempts to make the less obvious effects of projects, developments, institutions and services, the correctness of the direction of interventions visible, or further developments using the results of an already implemented project [9].

The SROI analysis can be prepared in many forms.

It is possible to analyze the social effects of all activities generated by an organization or of a specific project. There are two types of SROI analysis:

-Evaluation SROI method, which is a retrospective assessment of events and results that have already occurred.

-Forecasting SROI method that predicts how much social value is generated when activities meet expectations and the planned results are realized.

An important feature of the method is that it tries to express the created but not obvious values (possibly damages) in monetary terms, thus making it easier to communicate the impact of those settlement developments and social investments that are otherwise very difficult to detect.

Investors use the cost-benefit (CBA) analysis method in the normal analysis of projects to determine whether the investment or other activities are economical or not. The SROI is also based on the logic of the cost-benefit analysis, but can be considered a different method [10]. SROI is suitable for providing additional information to investors and business executives who, in making their investment decisions, are aware of its social, environmental impacts. As an indicator, SROI is calculated as follows: 
1. Determining the present value of a given social impact:

where SPV is the present value of the given social impact,

$$
\begin{aligned}
& \text { SPV }=\frac{\text { social impact value }}{1+r}+\frac{(\text { social impact value })^{2}}{(1+r)^{2}}+ \\
& \ldots+\frac{(\text { social impact value })^{t}}{(1+r)^{t}}
\end{aligned}
$$

$r$ the discount rate,

$t$ the duration.

the calculation of SROI indicator:

where

$C_{0}$ initial costs of the investment,

SROI social return on investments.

$$
S R O I=\frac{S P V}{C_{0}}
$$

Calculation of net NSROI indicator:

$$
\mathrm{SNPV}=\mathrm{SPV}-\mathrm{C} 0,
$$

where

SNPV the net present value of social impact,

$$
N S R O I=\frac{S N P V}{C_{0}},
$$

NSROI the net social return of the investment.

The SROI indicator is a ratio, which means how much social value a Hungarian Forint (HUF) investment creates in HUF. One of the problems that make it difficult to calculate the above formula is that it is not possible to assign monetary value directly to the social impact value. There is a need for methods that convert qualitative information to a quantitative value [8].

Another problem with the formula is that it is difficult to determine the appropriate „r" discount rate. According to the guidelines of the "Guide for calculating the social return on investment" [8], the recommended discount rate is $3.5 \%$. Due to the lack of comparative market interest rates, [9] argue that a range of discount rates may be applied (not only $3.5 \%$ ), considering that a higher discount rate reduces the return on investment. There is also need for a specific selection procedure according to [12] rather than the adoption of a standard discount rate based on the uncertainty over several years of social impacts.

There are different activities in each organization, so the representatives of organizations decide differently when analyzing the social return of their own activities. Consequently, it is not practical in itself to compare SROI indicators calculated for different activities of different organizations. Just as investors, in addition to information on financial returns, take information on financial returns into account when making an investment decision, social investors should also be aware of all the information produced as part of the SROI analysis, beyond the value of the SROI indicator. Organizations should emphasize to investors the importance of interpreting the SROI indicator in the context of a full analysis.

\section{Criticism of SROI}

There have been many criticisms of the SROI method in both scientific and applied literature. Monetary values assigned to social outcomes are problematic and often unreasonable, excessive, and overestimate the full impact of the activity under investigation [13],[14]. Changing social outcomes to value for money (applying the SROI method) could mean marketing the nonprofit sector, which undermines the ability to create and sustain a strong civil society [15].

However, the supporters of SROI argue that by assigning monetary value to non-financial results, these results can be understood and analyzed [16]. Another critical comment is that the SROI ratio is often published as the sole indicator of analysis, but it makes no sense to decide on a single indicator.

There is a need for some kind of forecast or similar calculations from other organizations to assess the impact. Another critical remark is that the SROI analysis is a resource-intensive process that can cause problems for charities, where human and financial resources may be limited, considering that significant input is required to determine the parameters of the social impacts under investigation $[17,18]$.

The SROI method was originally developed by the US-based Roberts Enterprise Development Fund (REDF) in the mid-1990s [19]. The criticism of the SROI model developed by REDF was the lack of standards, and that the results were unreliable and non-comparable. In the UK, the New Economics Foundation [20] further developed a widely used and standardized method since the late 1990s. NEF developed a six-stage framework to ensure that a wide range of organizations use the SROI method consistently. The SROI method contains a number of estimates, including discount rates, financial substitutes and applied impact assessment measures. They carry out a sensitivity analysis to determine which social impact is best for social return. In order to continuously monitor the social return on investments, it would be necessary to incorporate the SROI method into organizational operation. 


\section{Observations on SROI}

The SROI is different from most other financial assessment methods because it collects and analyzes information about the social value of resources used by activities. Most evaluations simply do not contain such information, not to mention the impact of these resources on society. Most of the other methods of cost-benefit analysis only measure the results of the activity under investigation in a natural unit.

The SROI is based on such analyses that make it easier to evaluate and compare investment opportunities by measuring the time value of money, the amount of money invested, and many other factors such as risk. If this measurement succeeds, one of the listed multi-dimensional information will be a number that can be assessed by a simple decision rule, ,the more, the greater the value the better”, so the best investment can be chosen. There are two suitable indicators for this: Net Present Value (NPV) and Return on Investment (ROI).

If the ROI is highlighted from the financial analysis and used for analyzing social environmental contexts (SROI) instead, then the previous results (NPV, ROI indicators) and the conclusions drawn from them may change in relation to the feasibility of an investment. The reason for this is that social expectations are the interests of the diverse environment, different cultures, the results of the SROI analysis can change the investors' return expectations for a given investment. These indicators can have a moderating effect on investors and their expectations of a single predefined (NPV, ROI) values of the indicators), the „more, the better" criteria for technology investments.

\section{Conclusion}

The application of SROI should not be rejected, by calculating this indicator it is possible to analyze several non-financial aspects, so more comprehensive conclusions can be drawn in the analysis of an investment, an activity. Some capital investment activities are not always reliable due to their impact on the environment and society. Investors completely ignore the consequences of these effects. However, the UN's "Sustainable Development Goals" document [21] illustrates that expectations for social and environmental change have increased significantly. This already influences the thinking of some governments, investors, and social organizations, which, when investing their capital, take the interests of the society and the environment into account in addition to private financial gain. The advantages and disadvantages of using the SROI method and the SROI indicator were analyzed above.
We emphasized that besides traditional financial analyses, economical calculations, the results determined by the SROI method show the extent to which an investment or activity results in benefit or loss to society. The results calculated by the SROI method do not appear in the financial statements but are useful for the company. It makes it possible to understand the social and economic environmental impacts of an investment or activity by attempting to quantify the individual effects by the SROI method.

\section{References}

[1] Fogarassy, C., Lukács, Á.,, Nagy, H.: 2008. Potential benefits of linking the Green Investment Scheme of the Kyoto Protocol with institutional voluntary markets like the Chicago Climate Exchange. In ENVECON - UK Network of Environmental Economics.

[2] Horvath, B., Mallinguh, E., Fogarassy, C.: 2018. Designing Business Solutions for Plastic Waste Management to Enhance Circular Transitions in Kenya. SUSTAINABILITY, 10(5).

http://doi.org/10.3390/su10051664

[3] Callahan, G.: 2001. What is an Externality? August 2001, 19, 8. The Free Market. The Mises Institute monthly.

http://www.mises.org/freemarket_detail.aspx?control $=367$.

[4] Mozsár F.: 2000. Az externáliák szerepe a regionális gazdasági teljesítmény magyarázatában és növelésében. In: Farkas B. - Lengyel I. (szerk.): Versenyképesség - regionális versenyképesség. SZTE Gazdaság Tudományi Kar Közleményei JATE Press, Szeged, pp: 100-114.

[5] Varian, H.R.: 1991. Mikroökonómia középfokon. Egy modern megközelítés. Közgazdasági és Jogi Kiadó Bp.

[6] Fogarassy C., Horvath B., Kovacs A.: 2015. Cross-sector analysis of the Hungarian sectors covered by the Effort Sharing Decision - Climate policy perspectives for the Hungarian agriculture within the 2021-2030 EU programming period. Apstract - Applied Studies in Agribusiness and Commerce 9: 4 pp. 17-24. Paper: 1789-7874, 8 p.

[7] Fogarassy C., Bakosne B. M.: 2014. Externality analysis of sustainable cattle breeding systems. Hungarian Agricultural Engineering Volume 26, pp. 5-10.

http://dx.doi.org/10.17676/HAE.2014.26.5

[8] Nicholls, J et al.: 2012. A Guide to Social Return on Investment. Office of the Third Sector UK.

[9] Yates B. T. - Marra M.: 2017. Introduction: Social Return on Investment (SROI). Evaluation and Program Planning 64. (2017) pp: 95-97. 
[10] Yates B. T. - Marra M.: 2017. Social Return on Investment (SROI): Problems, Solutions ... and is SROI a good investment? Evaluation and Program Planning 64. pp: 136-144.

[11] Emerson et al.: 2000. Social Return on Investment: Exploring Aspects of Value Creation in Non-profit Sector. San Francisco: The Roberts Enterprise Development Fund.

[12] Olsen, S. - Lingane, A.: 2003. Social Return on Investment: Standard Guidelines. Working Paper Series, Center for Responsible Business, UC Berkeley.

[13] McLoughlin, J, et al.: 2009. A strategic Approach to Social Impact Measurement of Social Enterprise: The SIMPLE methodology Social Enterprise Journal 5 (2), pp: 154-178.

[14] Wright, S. et al.: 2009. An Evaluation of the Transport to Employment (T2E) Scheme in Highland Scotland Using Social Return on Investment (SROI). Journal of Transport Geograpy, 17 (6), pp: 457-467. [15] Eikenberry, A. M. - Kluver, J. D.: 2004. The Marketization of the Non-profit Sector: Civil Society at Risk? Public Administration Review, 64 (2), pp: 112-134.
[16] Henry, G.: 2000 'Why not use?' New Direction for Evaluation 88. pp: 85-97.

[17] Newcomer, K. - Brass, C. T.: 2015 Forging a Strategic and Comprehensive approach to evaluation within public and non-profit organizations integrating measurement and analytics within evaluation. American Journal of Evaluation 37/1. pp: 80-99.

[18] Ryan, K. E. - DeStefano, L.: 2000 Evaluation as a democratic process: Promoting inclusion, dialogue, and deliberation. New Directions for Evaluation 85.

[19] Wachowicz, J. - Chun, S.: 2000. Social Return on Investment: Exploring Aspects of Value Creation in the Non-profit Sector REDF Box-Set, Vol. 2. pp: 132-170.

[20] NEF: 2009. Nemzeti Fejlesztési Terv Regionális Programok Irányító Hatósága, www.palyazat.gov.hu [21] UN: 2015. UN Department of Public Information: Sustainable Development of Goals Guidelines. 